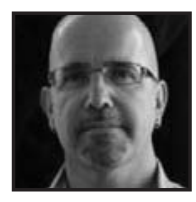

\title{
Through the Words of a Poet: Experiencing a Writing Journey
}

\author{
John J. Guiney Yallop, Acadia University
}

\section{ABSTRACT}

My PhD dissertation (Guiney Yallop, 2008) is an arts-based, autoethnographic, queer study. I wrote poetry to generate the data for my research. The first section of my dissertation consists of 46 poems, the first 23 of which are my Catholic terrain and the other 23 are my Education terrain. The poems are followed by an exegesis divided into 12 pauses. This article comes from the fifth pause where I explained the process I engaged in while writing the poetry and when I was putting the poems together in my dissertation. While each writer has her or his own processes when writing, I believe that making our processes explicit allows us and our readers to more fully appreciate how we construct our writing. As well as reflecting on the process, the reader may consider the content and the form of the writing; what are the poems saying and how are they saying it?

\section{First Confession-Conversing With My PhD Dissertation Supervisor}

The chickens didn't seem to fit because I was looking in at them...I needed to be inside/contained. The peeping tom seemed to fit with the screen on my bedroom window and how I was exposed in the church. I'll wait to hear from you. I may have to put the chickens back in. I guess I could do the bedroom and the chickens.

I'm having a little chuckle here. The content of our conversation is a poem in itself. 
Re: 'On Being A Teacher': I am trying to look back at my M. Ed. research (Guiney, 2002) and tease out some poetry to describe/show my journey to, in, and through a teaching career. I want to keep it to four poems maximum (maybe just three...one for to, one for in, one for through). Of course, these poems will help as I begin the more focussed writing once the proposal is accepted. The more I read (and write) the more comfortable I am becoming with the artistic aspect of my work (not that it's necessarily separate from the scholarly). What I mean is that I am becoming more comfortable with not reporting or even narrating about my life as Catholic and as Educator, but rather using those experiences to create a piece of work, a piece of scholarly work, that is evocative...educative... useful.

(E-mail communication to Cornelia Hoogland, May 18, 2006)

n the above e-mail, to my PhD Dissertation Supervisor, Cornelia Hoogland, I described some of my struggles and some of my decisions, and some of my reflections on those struggles and decisions, as I edited two specific poems I was working on at the time. The first poem is one that I was writing and editing for a presentation (Guiney Yallop, 2006a) I was giving at the Canadian Association of Curriculum Studies Celebration of Creative Works, a forum that has become a popular annual event held during the Canadian Society for the Study of Education Conference. The second poem was one of three I wrote for another performance at the conference itself (Guiney Yallop, 2006b). I share below some of the process I engaged in while writing those two poems.

I should mention here that some of my poems are composed using a computer from the beginning of the writing process to the end, while some are initially composed using handwriting. Such is the case with these two poems. "First Confession" was composed using a computer as my writing instrument, while "What Hate Is" (originally called "On Being A Teacher") was first composed and edited in handwriting. I do not have any particular preference for one of those practices or the other, but I do find myself more frequently writing poetry using handwriting, perhaps because I more often than not find myself in situations where I need to write but I don't have a computer available, it seems easier to carry a journal in my bag than a computer, but that may change. 


\section{First Confession—Development Of Early Drafts}

The original version of "First Confession" was sent to Cornelia for feedback on March 31, 2006. It was as follows:

\section{First Confession}

I wanted my first confession to be perfect;

I had practised my sins,

and the telling of them.

The t-shaped partition

brought to the front of the church

pretended to hide me and the priest

from the community.

I spoke quietly through the screen that framed the priest's profile.

I spoke too quietly for the priest.

"Get over here," he shouted.

"I can't hear a word you're saying."

Kneeling now

on the cold hardwood floor

with my tiny joined hands in the priest's lap,

looking up at his massive body

covered in a black cassock

and draped with a stole,

symbol of power,

I called out my sins,

the ones I could remember

and maybe more.

Absolved,

I returned to my place in the community

and recited in silence

my penance;

three Hail Mary's and one Our Father. 
Cornelia sent back the following reply on April 27, 2006. I want to note that this length of time between e-mails was not usual and that Cornelia was, at that time, also replying to drafts of my PhD dissertation proposal. Cornelia's comments were included in the document using a tracking feature. For ease of reading, I have typed the relevant comments below.

- To the lines "Get over here," he shouted, / "I can't hear a word you're saying." Cornelia wrote, "Did he really shout? Go back to the experience and be as exact as you can. Where is "over here"? bit confusing.

- In response to the line "I called out my sins," Cornelia wrote,"This is one of those energy lines I was talking about. Try this line first and see what happens. Be that young boy calling out his sins. Try it in your study. Get into the feeling of it. See where it takes you."

- Following the final verse, Cornelia wrote, "What in this shows your perfection? Show your desire to be perfect, don't tell."

Although I replied with another version the following day, I did think deeply about what Cornelia had written. Depth is not necessarily measured in time, although time also allows distance, as I discovered with the more time that elapsed between when I originally wrote the poems and when I wrote about the process of writing them. I laughed when I read Cornelia's suggestion to be "that boy calling out his sins" and to try calling them out in my study. I did. I was alone. I checked to make sure that the windows were closed; I didn't want the neighbours to hear me calling out my sins. I walked up and down the hall outside my study calling out those sins. I was reminded of practising my sins for confession as a child and as an adolescent-not so dramatically, but still convincingly. Confession is a performance.

The show, don't tell message came up often in my conversations and e-mail communications with Cornelia. I thought I was showing. I wasn't telling how frightened I was-how humiliated. What is a shout to a child? I knew that I had the pieces of the picture, the various parts of the story, but now I needed to place them together. How could I take my readers and listeners into the moment? In the second version, which I sent back to Cornelia on April 26, 2006, I took Cornelia's advice and began my poem with what she calls "one of those energy lines." I also listed the sins I was calling out in the hall outside my study. 


\section{First Confession}

I called out my sins

with my knees pressed

into the cold hardwood floor

and my tiny hands joined

over the priest's lap

as I looked up at his massive body.

"I told a lie one or two times, Father.

I said bad words four or five times, Father.

I disobeyed my parents two or three times, Father."

I had wanted my first confession to be perfect.

My sins were supposed to slide through

from my mouth

to the priest's profile

framed in the screen that reminded me

of the one dad had put over the window to our henhouse.

Behind the t-shaped partition

which stood at the front of the church

I whispered my sins

like I would whisper to the chickens through the window.

"Get over here," he barked.

"I can't hear a word you're saying."

And like the frightened chickens

when the dog put his paws up to the window

I recited my penance:

“Hail Mary

and

Our Father.

Three times.

Amen." 
Before Cornelia replied, I sent another version on May 18, 2006. It was at this point that I had decided that this poem would be the one I would be presenting at the Canadian Association of Curriculum Studies Celebration of Creative Works. The changes were significant. Below, I show the changes, in brackets, I made to the poem.

\title{
First Confession
}

I called out my sins

with my knees pressed

into the cold hardwood floor

and my tiny hands joined

over the priest's lap

as I looked up at his massive body. (No changes to the first six lines.)

"I told a lie two or three times, Father. (Quantity changes to sins.)

I said bad words four or five times, Father.

I disobeyed my parents once or twice times, Father." (Quantity changes to sins.)

I had wanted my first confession to be perfect. (Line moved to speed pace / show anxiety.)

My sins were supposed to slide through

from my mouth

to the priest's profile

framed in the screen

like the one over

my bedroom window. (From the verse above, I removed "that reminded me / of the one dad had put over the window to our henhouse.")

\begin{abstract}
A moment earlier (This is a new line.)
behind the t-shaped partition

which stood at the front of the church

I had whispered my sins

like I would whisper my prayers at night. ("my prayers at night" rather than "to the chickens through the window" seemed like a better contrast to confession, and a better link with it, since the priest in confession represents God.)
\end{abstract}

"Get over here," he shouted. (Back to "shouted" instead of "barked.")

"I can't hear a word you're saying." 


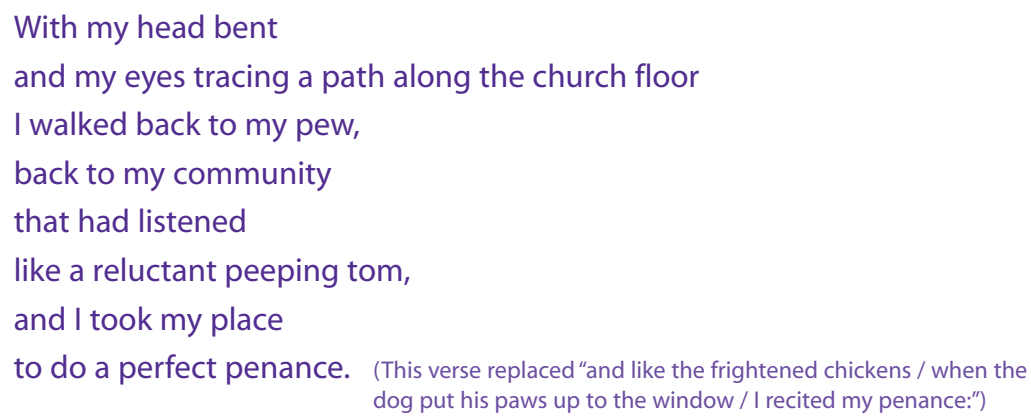

Hail Mary

and

Our Father

Three times.

Amen. (Again, as above, I pushed the last lines together to quicken the pace and show anxiety.)

What is absent, I hope, from this poem, what I did not want to put in there, is my anger. My anger is present in me as an adult. It is not the child's experience. The child is afraid and humiliated. I want the reader to feel that fear and that humiliation, just as I felt it as I wrote the poem, and just as I feel it whenever I read the poem. But it is difficult to put my anger aside, to not allow that adult experience of that emotion to influence me as I write. "Be that boy," Joan Barfoot, Writer in Residence at The University of Western Ontario, 2006-2007, told me later (in conversation) while discussing other poems that I would include in my dissertation. Joan's advice echoed what Cornelia noted in her written responses to my first draft of the poem. "Be that boy" was something I tried to remember as I edited all of my poems written from or about the experiences of my childhood.

In her next reply, Cornelia asked, "What happened to the chickens-I really liked them" (E-mail communication from Cornelia Hoogland, May 18, 2006). That was followed by my reply - the passages from the e-mail at the beginning of this article. Two days later, in a very detailed reply, Cornelia highlighted the importance of this struggle I was having in writing my poems.

JOHN THIS IS MATERIAL THAT YOU NEED TO COLLECT, IE THE STRUGGLE TO WRITE YOUR POEMS IS AS VALUABLE AS THE POEMS IN TERMS OF THE DISSERTATION. Using those experiences to create a piece of work - IS YOUR CONCERN. FINDING THE DIFFERENT WAYS TO DO THAT, THE DIFFERENT 
VOICES, TONES, RELATIONSHIPS.

(E-mail communication from Cornelia Hoogland, May 20, 2006, emphasis in the original)

The next—the fourth — version of the poem I sent to Cornelia on May 25, 2006. This is also the version that I performed on May 28 (Guiney Yallop, 2006a). In this version I changed the title to "Confession." This, I stated, was "an effort to transplant experience" (E-mail communication to Cornelia Hoogland, May 25, 2006). By that I meant that I was moving the poem to a more general experience, an experience that I would have had many times with many priests, to protect the anonymity of the priest to whom I had made my first confession. I also thought that the new title would make the poem more evocative because it could be any confession, as opposed to just a first confession. I subsequently changed my mind again and, in the next version, changed the title back to "First Confession. "I realized that I was not really sure when this event took place. It could have been my first confession or it could have been another confession. The priest to whom I had made my first confession was long since deceased, and there were numerous priests to whom I had made other confessions. Also, it did not matter when I actually had this experience; it was the content of the poem that mattered. Finally, I believe that the evocative power of an experience is not in how general it tries to be, but in how real it feels.

\section{Confession}

I called out my sins

with my knees pressed

into the cold hardwood floor

and my tiny hands joined

over the priest's lap

as I looked up at his massive body.

"I told a lie two or three times, Father.

I said bad words three or four times, Father.

I disobeyed my parents once or twice, Father."

I had wanted to make a perfect confession.

My sins were supposed to slide through

from my mouth 
to the priest's one-eyed profile

framed in a screen

like the one Dad had put over the window

to our henhouse;

the priest sat inside

enthroned

like some giant bird

staring,

an oversized crow.

(One for sorrow.)

But I had whispered my sins

like I would whisper my prayers at night.

"Get over here," he shouted.

"I can't hear a word you're saying."

I entered the henhouse,

now the crow's sanctuary,

and then to the dispersed flock

that had gathered round outside

like reluctant peeping toms,

I turned and took my place

to attempt a perfect penance.

“Hail Mary

and

Our Father.

Three times.

Amen."

The henhouse was back, but without the chickens specifically mentioned.

\section{First Confession-Thoughts From Don McKay}

On October 13, 2006, with the title changed back to "First Confession,"I sent a copy of this poem, and nine others, to Don McKay, Writer in Residence at Memorial University of Newfoundland during the Fall Term of 2006. The generosity of Don's handwritten comments on this one poem alone was enormous. Equally detailed 
responses were handwritten on the other nine poems. As well, Don included a personal letter with some general comments about the poems. I was honoured that Don McKay was even looking at some of my poems. That he would give them such attention was overwhelming. I remain truly grateful to this man who Cornelia described as "one of the best poets in Canada" (E-mail communication from Cornelia Hoogland, October 13, 2006).

Don, like Cornelia, brought up the "'show don't tell' principle" particularly with regards to the first verse. He also suggested a sharpening of the image, from the child's point of view, of "the massive body." Don felt that I "should emphasize the difference between the standard scene in the confession box and what happened." Don suspected that my "narrative structure (flashing back)...[was] getting in the way of the powerful story and the child's p.o.v.- - which would likely produce a story." Don suggested "starting with the henhouse comparison, then the confessional with the crow replacing the hens, then the scene kneeling before the priest."

After a careful reading of Don's comments, I further revised the poem on November 27, 2006.

First Confession

The shutter opened

to the priest's one-eyed profile

framed in a screen

like the one Dad had put over the window

to our henhouse;

the priest sat inside

enthroned

like some giant bird

staring,

an oversized crow.

(One for sorrow.)

In a good confession

sins would slide through

from my mouth

to the priest's alerted ears,

but I had whispered my sins

like I would whisper my prayers at night. 
"Get over here," he shouted.

"I can't hear a word you're saying."

My knees pressed

into the cold hardwood floor

and my tiny hands joined

over the priest's knees

as I looked up over his belly.

"I told a lie two or three times, Father.

I said bad words three or four times, Father.

I disobeyed my parents once or twice, Father."

\section{First Confession—Finding The Final Version}

This would remain the version of the poem I would use for my dissertation, except for a few other changes. In an e-mail on December 13, 2006 Cornelia asked that I search for another way of saying "had put" in line four of the poem. She also suggested that I make the last two lines of stanza two present past instead of conditional. In another e-mail communication on January 22, 2007, in regards to the last line, in brackets, at the end of stanza one, Cornelia writes, "This tempers the image considerably, tender(izes) it. Perhaps omit." I agreed. The most recent version of the poem appears below and on page 16 of my dissertation. After reading the most recent version of the poem, Connie Russell, one of the members of my PhD Dissertation Committee commented, "Hmm, the bird imagery evokes for me connections to human relationships to animals, sometimes oppressive (in eg of hens)" (E-mail communication from Connie Russell, February 26, 2007). This was a reminder for me of how my poetry might connect with people in their experience and their values; Connie's research involves how we humans relate to the other creatures with whom we share this planet.

First Confession

The shutter opened

to the priest's one-eyed profile

framed in a screen 
like the one Dad fitted over the window

to our henhouse;

the priest sat inside

enthroned

like some giant bird

staring -

an oversized crow.

In a good confession

sins would slide through

from my mouth

to the priest's alerted ears,

but I whispered my sins

like I whispered my prayers at night.

"Get over here," he shouted.

"I can't hear a word you're saying."

My knees pressed

into the cold hardwood floor

and my tiny hands joined

over the priest's knees

as I looked up over his belly.

"I told a lie two or three times, Father.

I said bad words three or four times, Father.

I disobeyed my parents once or twice, Father."

\section{What Hate Is—Developing Early Drafts}

The development of the poem "What Hate Is" was similar to that of "First Confession."This poem, however, started off on May 17, 2006 in handwriting (or printing) in one of my journals. On May 17, 2006, I sent the following version, with the title change, to Cornelia: 


\section{On Being A Teacher}

Hate was biting at my heels

from the first day

I started teaching,

and I ignored it.

Hate nudged its unwelcome elbow

into my back.

Hate left spit on my desk

and graffiti on the walls of our classrooms.

Hate sent notes

and made telephone calls

to administrators

to express concern,

and some administrators had concerns, too;

Hate didn't have a problem

with me being gay,

but it wasn't appropriate

to tell the students.

Being gay has nothing to do with teaching,

after all;

nothing at all.

Hate was biting at my heels

from the first day

I started teaching,

and I ignored it.

I ignored it

until one day when Hate

put its long fingers around my neck

and I couldn't speak,

words jamming in my throat

like an apocalyptic rush hour.

I ignored it

until it was almost too late. 


\author{
Now, \\ when I put my hands to my neck, \\ I can feel the scars \\ left by Hate's long fingers; \\ shirt collars wrap around pain, \\ and my throat remains raw \\ where words travel \\ always aware of risks, \\ and the bite marks \\ on my heels \\ cause my feet to fit uncomfortably \\ inside any shoes.
}

Hate contours the body.

Having told me that I can switch points of view in "First Confession," Cornelia writes,

I think this is also true when it comes to difficult subject matter such as 'On Being A Teacher.' How is the narrator positioned in that poem? Who is hate? What are the characteristics that hate takes on in your poem? Are they consistent? are they various? (ie if you suggest a vicious dog "biting at my heels" do you develop that metaphor? How? Do you drop it?)

On a more general level (which is more to the point of a doctoral dissertation which requires this kind of discussion) poets need to ask questions such as: who are the characters in this poem? Who is privileged? Where does that privilege appear in the poem? Who is introduced but then dropped? Who enters late in the poem? Who is given lines of dialogue?

(You can see these are the very questions that gender studies and gay studies might be concerned with. The poets are not looking at this from the point of view of group behaviour however but importantly from the pt of view of language. How lines in a poem also engage struggle, inclusiveness, anger, distance, control, etc.).

(E-mail communication from Cornelia Hoogland, May 20, 2006, emphasis in the original) 


\section{What Hate Is-Thoughts From Two Other Writers In Residence}

Cornelia's comments helped me shorten the poem, to get rid of what was unnecessary. Although Joan Barfoot did not read this particular poem, this getting rid of excess was something, when I met with her about the selection of poems that she had read and commented on in her role as Writer In Residence at The University of Western Ontario, that she also reminded me to always do with my poems. Joan told me that she liked my poems because they were clear, that I was to-the-point, that I didn't use flowery language. She added that "complex language doesn't necessarily come from complex thought" (in conversation, November 23, 2006). Although when I first met her, Joan referred to herself as "not a poet," her words regarding complex language were similar to those of poet Louise Glück:

The poet is supposed to be the person who can't get enough words like 'incarnadine.' This was not my experience....What fascinated me were the possibilities of context. What I responded to, on the page, was the way a poem could liberate, by means of a word's setting, through subtleties of timing, of pacing, that word's full and surprising range of meaning. It seemed to me that simple language best suited this enterprise; such language, in being generic, is likely to contain the greatest and most dramatic variety of meaning within individual words. (Cited in Silberg, 2002, p. 138)

It was a lack of clarity in one of my poems that Christopher Dewdney, Writer in Residence at The University of Windsor 2006-2007, referred to earlier that month when I spoke with him by telephone about some of my poems that he had read. He said that that poem needed to be more concrete. "Obscurity," he said, "is unfriendly to the reader, but ambiguity can be a mystical friend" (telephone conversation, November 13, 2006). It was this tension between the extremes of telling and being obscure, aiming to balance with clarity and ambiguity that I was dealing with and striving for as I edited my poems. 


\section{What Hate Is—A Shorter Version For The First Performance}

The third version of "On Being A Teacher," the version which became part of my presentation at the Canadian Society for the Study of Education Conference (Guiney Yallop, 2006b), contains just five more than half the words of the previous version. (Note:Those five words are in the new, longer, title.) The other two poems in that presentation were not included in the poetry for my dissertation.

\section{On Being A Teacher \\ (or What Hate Is Like)}

Hate is like a mad dog
biting at my heels
from the first day
I started teaching.

Hate is like an unwelcome elbow

in my back.

Hate is like spit on my desk

and homophobic graffiti on our classroom walls.

Hate is like letters

and telephone calls

to administrators

to express concern.

Hate is like administrators' concerns, too.

Hate is like long fingers around my neck

and not being able to speak, words jamming in my throat

like an apocalyptic rush hour.

Hate is like some well-oiled apparatus

that contours the body;

we get used to it. 


\section{What Hate Is—More Thoughts From Don McKay}

It was the above version that I sent to Cornelia as part of draft five of my PhD dissertation proposal on July 4, 2006 and as part of draft six on July 13, 2006. It was draft six that my PhD Dissertation Committee received and which I defended in September 2006. This was also the version of the poem that I sent to Don McKay on October 13, 2006. Again, Don was enormously generous with his comments. Don asked that I [c]onsider moving into full metaphor from simile." He stated that this "creates a more dramatic emphasis." Don also suggested enjambment later in the poem, or even earlier. He concluded with,"I wonder if this poem is finished with you yet.You might revisit it, try for occasional specificity and nuance."

"No, Don, this poem is not through with me,"I thought after reading Don's comments. Taking Don's advice, I went full metaphor.I also worked at showing, rather than telling; I think this is what Don meant when he wrote "try for occasional specificity and nuance." On November 29, 2006, I even considered changing the title to "Homo Hatred" but eventually decided to focus on the word hate; I titled the poem "What Hate Is."

\section{What Hate Is}

Hate is a mad guard dog biting at my heels.

Hate is an unwelcome elbow in my back.

Hate is spit on my desk and This teacher sucks cock. on the chalkboard.

Hate is letters and telephone calls to administrators

to express concern about me wearing that t-shirt, or kissing a man in the parking lot, or looking at construction workers outside school, hate is 
long fingers around my neck

not being able to speak,

words jamming in my throat

like an apocalyptic rush hour.

Hate is a well-oiled apparatus

that contours the body;

we get used to it.

\section{What Hate Is_Finding The Final Version}

Further changes were made in the December 5, 2006 version, which was sent to Cornelia as part of my collection(s) of poetry, and to which she had no suggestions for additional changes. Responding to another revised version of the poetry for my dissertation, Cornelia noted in an e-mail communication on January 22, 2007, "Gee, this poem has improved 100\%. What a difference!" One considerable difference was size; at 102 words, the poem was now 100 words shorter than the original typed version. Another significant change was the use of metaphor as opposed to simile and the inclusion of more specific instances of what hate is. This was the version that went to my PhD Dissertation Committee, and the version which appears below and on page 54 of my dissertation.

\section{What Hate Is}

Hate is a mad guard dog

biting at my heels.

Hate is an unwelcome elbow

in my back.

Hate is spit on my desk

and This teacher sucks cock.

on the chalkboard.

Hate is letters and telephone calls

to administrators 
to express concern about me wearing that t-shirt,

or kissing a man in the parking lot,

or looking at construction workers outside school, hate is

long fingers around my neck

not being able to speak,

words jamming in my throat

like an apocalyptic rush hour.

Hate is a well-oiled apparatus

that contours the body;

we get used to it.

\section{When Is A Poem Finished?}

Margaret Atwood was once asked, in an interview conducted by Norm Sacuta, how she knew when a poem was finished. She responded, "When nothing more can be done. It's the same with a novel. You come to a point where it's either good or bad or mediocre, but it's finished" (Bowling, 2002, p. 224). I had a similar experience with concluding the work on my poems. There came a point at which I felt nothing more could be done. Of course, there is always the possibility of doing something else with a poem, but that doesn't necessarily improve the poem. If the poem is finished and I continue to chip away at it, it means that I am not prepared to let it go and I could harm the poem - I could limit the impact that it could have on others. I need to let go of a finished poem, so that it can do its work.

And it is this finished work that I want to speak to here. Arthur Frank (1995) grappled with the accumulation of editorial advice on his writing. While I invited and welcomed the comments I received on my poetry, the final decisions as to what to include in the finished versions of my poems were mine. That is not to say that I was not influenced by what others wrote or said about the poems. I was. I believe that such influence is a part, a welcome part, of writing, of reflecting, of researching, of living. 


\section{Some Final (for now) Thoughts On (my evolving) Process}

The purpose of sharing this part of this writing journey is to show the reader what the process of editing and reflection looks like for a poet-at least, what it looks like for this poet. It also shows how the poems, two specific poems, evolved over time. I identify with Richard Siken, author of Crush (2005) who, in an interview with James Hall (2006), describes his writing process:

I knew that I wanted this book to be cohesive, so I knew from the beginning that the poems would have to speak to each other. But generally my writing process looks a lot like everyone else's revision process. I get scraps of language in my head, either music or content, and I scribble them down. When I get a good sized stack of scribbled pages I type them up and start writing in the margins, overwriting, rewriting, annotating insertions, gluing parts over other parts. When the pages get too thick or too hard to read, I retype them and continue the process. When I've generated enough pages, I start making maps and lists of plots, themes, movements. Then I tape the text to the wall, continuously, at eye-level. That makes a horizontal line that usually circles a room or two. I tape versions and revisions vertically from their original, and then I've got a wall of text I can walk through, pace through, while I fine tune and polish. That's how I wrote Crush, and that's how I'm approaching the next work. When I got my copy of Crush from the press, I was strangely surprised. It looked so small. It fit in my hand. My version was a four-drawer file cabinet filled with versions, blueprints, appendices, collages, cartographies, and an exegesis. My version was a house of text I could walk through. (p. 234)

Cornelia described to me her process of putting a book together. She spreads all of her poems out on the floor and then works at finding poems that connect with one another, that might be seen as flowing from or into one another. If she finds beginning lines in one that have an image or a metaphor that was similar to the ending lines in another she "gets quite excited about that" (in conversation).

My own process is evolving and incorporates some of the practices of both Richard Siken and Cornelia Hoogland. For the poetry for my dissertation I used file folders. Initially I had two folders-one for my Catholic poems and another for my Education poems. I used two colours of paper clips (green for Catholic and red for Education) to keep versions of the poems together in chronological order with the 
most recent version on top. The files were bulging, even though I know that I did not have hard copies of all the versions of the poems. I stopped trying to bring the two file folders to meetings with Cornelia. This process continued until I decided that I needed a separate file for each poem. I kept all, or most, of the versions of each poem in its separate file, again with the most recent version on top. This was useful when I wanted to work on one particular poem or when I wanted to change the order of the poems in my dissertation. For the order of the poems in my dissertation I was also attempting to follow a chronological order drawn from my remembered and imagined lived experiences. I did not always hold to this order, however; when a poem seemed to work better in another location, I ignored chronology and went for aesthetic effect. When the order of the poems changed in any given version of my dissertation, the order of the files also changed in my filing cabinet.

Rereading the versions of the two poems I discuss in this article, and indeed the versions of my other poems for my research, takes me through the experience in new, renewing, ways. While the experience is made explicit above, the experience is inherent in the most recent versions of the poems as they appear in my dissertation. The reader comes to know this experience by engaging with the poems, by listening to what the poems are saying, and by noticing choices-the choices I made in constructing the poems and how the poems construct me and my experiences.

\section{References}

Bowling, T. (Ed.). (2002). Where the words come from: Canadian poets in conversation. Roberts Creek: Nightwood Editions.

Frank, A.W. (1995). The wounded storyteller:Body, illness, and ethics. Chicago: University of Chicago Press.

Guiney, J. J. (2002). School life for gays: A critical study through story. Unpublished Master of Education, Brock University, St. Catharines.

Guiney Yallop, J. J. (2006a). Confession. Performance given at Canadian Association of Curriculum Studies Celebration of Creative Works, York University, Toronto.

Guiney Yallop, J. J. (2006b). Queering a path to, in, and through a teaching career.
Performance given at Canadian Society for the Study of Education Conference, York University, Toronto.

Guiney Yallop, J. J. (2008). OUT of place: A poetic journey through the emotional landscape of a gay person's identities within/without communities. Unpublished doctoral dissertation. The University of Western Ontario, London.

Siken, R. (2005). Crush. New Haven: Yale University Press.

Siken, R., \& Hall, J. (2006). The poetry of hostile witness. Gulf Coast, 18(1), 220-234.

Silberg, R. (2002). Reading the sphere: A geography of contemporary American poetry. Berkeley, CA: Berkeley Hills Books. 


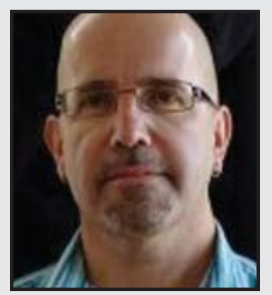

John J. Guiney Yallop is a parent, a partner, and a poet who was awarded his PhD in 2008 by The University of Western Ontario. His dissertation, OUT of place: A poetic journey through the emotional landscape of a gay person's identities within/without communities, is a poetic inquiry where he wrote a book of poetry and followed the book of poetry with an exegesis in which he reflected on the poetry and the experience of doing this type of research. Dr. Guiney Yallop is currently an Assistant Professor in the School of Education at Acadia University. His research includes poetic inquiry, narrative inquiry, autoethnography, and performative social science.

LINK TO:

http://education.acadiau.ca/dr-john-guiney-yallop.html http://writers.ns.ca/writers/G/guineyyallopjohnj.html 